\title{
Correction to: Prevention of spinal fusion post-operative wound infections in pediatric patients with scoliosis: a quality improvement initiative
}

\author{
Elizabeth Partridge $\mathrm{e}^{1,3}$ (Dean Blumberg ${ }^{1,3} \cdot$ Rolando F. Roberto ${ }^{2,3}$
}

Published online: 10 February 2021

(c) The Author(s) 2021

\section{Correction to: Spine Deformity \\ https://doi.org/10.1007/s43390-020-00274-3}

The original version of this article unfortunately contained a mistake. The following affiliation of all three authors had not been included and was added retrospectively: Shriners Hospitals for Children, Northern California, Orthopedics, Sacramento, CA, USA.

The original article has been corrected.
Open Access This article is licensed under a Creative Commons Attribution 4.0 International License, which permits use, sharing, adaptation, distribution and reproduction in any medium or format, as long as you give appropriate credit to the original author(s) and the source, provide a link to the Creative Commons licence, and indicate if changes were made. The images or other third party material in this article are included in the article's Creative Commons licence, unless indicated otherwise in a credit line to the material. If material is not included in the article's Creative Commons licence and your intended use is not permitted by statutory regulation or exceeds the permitted use, you will need to obtain permission directly from the copyright holder. To view a copy of this licence, visit http://creativecommons.org/licenses/by/4.0/.

The original article can be found online at https://doi.org/10.1007/ s43390-020-00274-3.

Elizabeth Partridge

epartridge@ucdavis.edu

1 University of California Davis Medical Center, Pediatric Infectious Disease, Sacramento, CA, USA

2 University of California Davis Medical Center, Orthopedics, Sacramento, CA, USA

3 Shriners Hospitals for Children, Northern California, Orthopedics, Sacramento, CA, USA 